\title{
Does the Portal Pressure Changes have an Effect on Liver Functions of Donor Hepatectomy in Living Donor Transplantation
}

\author{
MOHAMMED KHATTAB, M.Sc.; AHMED H. KHALIL, M.D., M.R.C.S., M.Sc.; KAREEM HOSNY, M.D.; \\ MOSTAFA ELSHAZLY, M.D.; AYMAN SALAH ELDIN, M.D. and ADEL HOSNY, M.D.
}

The Department of General Surgery, Faculty of Medicine, Cairo University

\begin{abstract}
Background: Living donor liver transplantation has now became an alternative for cadaveric liver transplantation. Raised portal pressure and over perfusion can injure the remnant liver and leads to hepatic dysfunction. This prospective study evaluates the portal pressure changes that occurs during donor hepatectomy and its effect on liver functions.
\end{abstract}

Aim of Study: We aimed to study the portal pressure changes during donor hepatectomy and its relation to liver functions.

Patients and Methods: This prospective study included 30 adult living donors who underwent right hepatectomy in Liver Transplantation Unit, Faculty of Medicine, Cairo University during the period between June 2015 to October 2016. Portal venous pressure was measured intra-operatively using wide gauge cannula preclamping and postclamping of portal vein during donor hepatectomy. Post-operative liver functions in the form of daily ALT, AST, total bilirubin, direct bilirubin, INR and Albumin were done daily till normalization.

Results: In this study the mean portal pressure before and after clamping of right portal vein was $9.9 \mathrm{mmHg}$ and 15.23 $\mathrm{mmHg}$ respectively. The mean changes in portal pressure were significant $(p<0.001)$.

The higher the changes in portal pressure the higher were the serum levels of day 1, 3 and 5 ALT, day 3 and 5 AST, day 5 total bilirubin and day 5 albumin. The higher the portal pressure changes gave the longer the duration of normalization of (ALT, AST, bilirubin, and albumin).

Conclusion: This study has demonstrated a significant rise in PVP post clamping of right portal vein. The higher the changes in portal pressure the higher serum levels of postoperative day 1, 3 and 5 ALT, day 3 and 5 AST, day 5 total bilirubin and day 5 albumin, the higher the portal pressure changes gave 'the longer the duration of normalization of (ALT, AST, bilirubin, and albumin). However, the delayed functional regeneration did not proceed to liver failure in non of the cases.

Key Words: Liver transplantation - Living donor - Portal pressure - Liver functions - Liver dysfunction.

Correspondence to: Mohammed Khattab, The Department of General Surgery, Faculty of Medicine, Cairo University

\section{Introduction}

DONOR safety is of high value in living donor liver transplantation. Some donors decompensate to great extent despite adequate residual liver volume [1].

Liver regeneration will be initiated immediately after the liver donation surgery. This process involves numerous molecular events and gene expressions. Hemodynamic changes in pressure and shear stress are also known as two of the most influential factors [2].

The increase in portal pressure and mesenteric flow causes sinusoidal endothelial and Kupffer cell injury with release of inflammatory cytokines [3].

As a consequence, the liver regeneration and functional recovery will be hindered. In animal studies, 80 to $85 \%$ hepatectomy resulted in prolonged elevation in serum transaminases, with significant increase in TNF-alpha and PGE2 associated with progressive necrosis of the remnant liver [4].

The donor's remnant liver may not regenerate to the full volume that it had before the operation. However, most of the donors achieved normal liver synthetic function within 1 post-operative week without complications [5].

The post-operative changes in liver function test values following liver donation by living adults, the peak AST, ALT, and total Bilirubin values were

\footnotetext{
Abbreviation:

PVP: Portal venous pressure.

PVF: Portal venous flow.

TNF: Tumor necrosis factor.

PGE: Prostaglandin E2.
} 
found to be higher in right-lobe donors than leftlobe donors [6].

This regeneration requires an appropriate PVF and PVP and the strength of the regenerative stimulation is proportional to the increase of PVF up to the onset of hepatocytes injury [7].

\section{Patients and Methods}

This prospective study included 30 adult living donors who underwent right hepatectomy in the Liver Transplantation Unit, Faculty of Medicine, Cairo University during the period between June 2015 to October 2016.

Inclusion criteria included an age from 21 to 50 years with a residual liver volume $>35 \%$. Exclusion criteria included donors with positive viral serology (hepatitis B or C virus, IgM for CMV, herpes simplex, and HIV). A body mass index $>30 \mathrm{~kg} / \mathrm{m}^{2}$, liver pathology (hemangioma, bilharzial fibrosis) or trifurcated portal vein on portal venography and donors with major medical disorders were excluded.

\section{Preoperative preparations:}

Laboratory and radiological investigations included Complete Blood Count (CBC), coagulation profile, liver and kidney function tests, and viral serology. Radiological investigations included abdominal Ultrasound (US), triphasic Computed Tomography (CT) of the abdomen, chest, MRCP, CT angiography to delineate the vascular anatomy of the hepatic artery, hepatic veins and portal vein CT volumetry was done for all donors to calculate the graft weight recipient ratio and the residual liver volume of the donor. Percutaneous ultrasoundguided liver biopsy was done to assess hepatosteatosis.

\section{Donor surgery:}

We followed the routine surgical steps of donor Rt lobe hepatectomy in the form of mobilization of right lobe and hilar dissection to identify portal vein, right hepatic artery and right bile duct.

Portal Venous Pressure (PVP) was measured using a wide pore cannula inserted into the main portal vein. The other end was connected through an extension-arterial line to a pressure transducer. Then the right portal vein was clamped and the pressure was measured again Figs. $(1,2)$.

The normal range for direct measurement of PVP values was considered to be 7 to $12 \mathrm{mmHg}$.

\section{Post-operative follow-up:}

Liver function tests were done daily till normalization. In addition to Kidney function tests, coagulation profile, hemoglobin and bilirubin levels of the drainage, and abdominal ultrasound and duplex of the hepatic vessels were done daily.

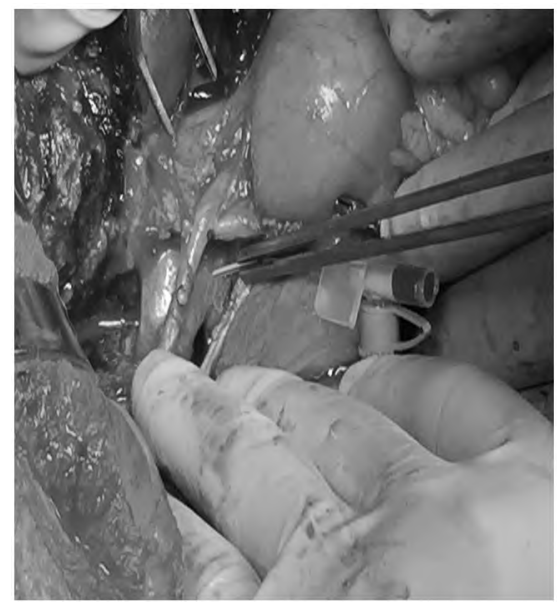

Fig. (1): Insertion of wide gauge cannula in to the main portal vein.

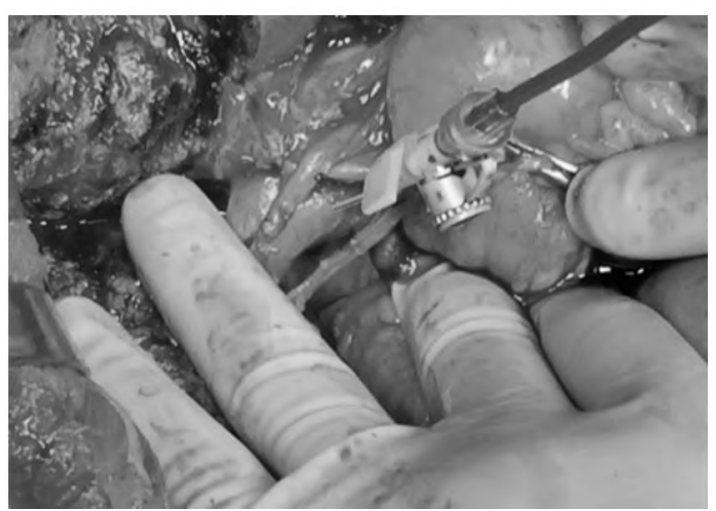

Fig. (2): Connecting the cannula to a pressure transducer via an arterial line.

\section{Results}

This prospective study included 30 adult living donors. The demographic data is shown in (Table 1).

Table (1): Demographic data of living donors.

\begin{tabular}{lllccc}
\hline $\begin{array}{l}\text { Total } \\
\text { number } \\
\text { of cases }\end{array}$ & $\begin{array}{l}\text { Range } \\
\text { of age }\end{array}$ & $\begin{array}{c}\text { Mean } \\
\text { age }\end{array}$ & Male & Female & $\begin{array}{c}\text { Mean BMI } \\
\left(\mathrm{kg} / \mathrm{m}^{2}\right)\end{array}$ \\
\hline 30 & $\begin{array}{l}21-45 \\
\text { years old }\end{array}$ & $\begin{array}{l}29.67 \\
\text { years old }\end{array}$ & 24 & 6 & 24.37 \\
\hline
\end{tabular}

\section{Portal pressure $(\mathrm{mmHg})$ :}

In this study the mean portal pressure before and after clamping of right portal vein was 9.9 $\mathrm{mmHg}$ and $15.23 \mathrm{mmHg}$ respectively. The mean 
changes in portal pressure was significant $(p<0.001)$ as shown in (Table 2).

Correlation between changes in portal pressure and level of ALT, AST, INR, bilirubin, Albumin in day 1, 3 and 5 post-operative and their duration to normalize.
The higher the changes in portal pressure the higher serum levels of day 1, 3, and 5 ALT, day 3 and 5 AST, day 5 total bilirubin and day 5 albumin.

The higher the portal pressure changes the longer the duration of normalization of (ALT, AST, bilirubin, and albumin).

Table (2): Portal pressure pre, post clamping and changes in portal pressure and significance of portal pressure changes.

\begin{tabular}{lccccc}
\hline $\begin{array}{l}\text { Portal venous pressure } \\
\text { (PVP) }\end{array}$ & $\begin{array}{c}\text { Minimum } \\
(\mathrm{mmHg})\end{array}$ & $\begin{array}{c}\text { Maximum } \\
(\mathrm{mmHg})\end{array}$ & $\begin{array}{c}\text { Mean } \\
(\mathrm{mmHg})\end{array}$ & $\begin{array}{c}\text { Standard } \\
\text { Deviation }\end{array}$ & $\begin{array}{c}p \text { - } \\
\text { value }\end{array}$ \\
\hline Portal pressure pre clamping & 7.00 & 11.00 & 9.90 & 1.16 & $<0.001$ \\
Portal pressure post clamping & 11.00 & 19.00 & 15.23 & 2.49 & \\
Changes in portal pressure & 2.00 & 8.00 & 5.33 & 1.69 & \\
\hline
\end{tabular}

Table (3): Shows serum level of ALT, AST, bilirubin, INR, Albumin in day 1, 3, 5 postoperative and their duration to normalize.

\begin{tabular}{lllll}
\hline Liver function tests & Minimum & Maximum & Mean & $\begin{array}{l}\text { Standard } \\
\text { Deviation }\end{array}$ \\
\hline Albumin D1 & $2.90 \mathrm{gm} / \mathrm{dl}$ & 4.30 & 3.73 & .37 \\
Albumin D3 & 3.10 & 3.80 & 3.46 & .22 \\
Albumin D5 & 2.90 & 3.90 & 3.41 & .33 \\
Albumin D to normal (days) & 1.00 & 8.00 & 4.00 & 2.77 \\
Bil T D1 & $0.80 \mathrm{mg} / \mathrm{dl}$ & 3.80 & 1.78 & .83 \\
Bil T D3 & 0.90 & 3.90 & 2.49 & .83 \\
Bil T D5 & 0.60 & 4.00 & 1.86 & .96 \\
Bil T D to normal (days) & 2.00 & 8.00 & 5.90 & 1.83 \\
Bil D D1 & 0.30 & 1.78 & .73 & .41 \\
Bil D D3 & 0.40 & 2.30 & 1.14 & .47 \\
Bil D D5 & 0.30 & 2.50 & .74 & .56 \\
Bil D D to normal (days) & 3.00 & 8.00 & 5.23 & 1.30 \\
INR D1 & 1.00 & 2.70 & 1.60 & .40 \\
INR D3 & 1.17 & 2.30 & 1.54 & .30 \\
INR D5 & 1.00 & 1.50 & 1.21 & .14 \\
INR D to normal (days) & 4.00 & 9.00 & 6.13 & 1.17 \\
ALT D1 & $153.00 I U / d 1$ & 701.00 & 339.30 & 164.13 \\
ALT D3 & 99.00 & 511.00 & 255.77 & 126.17 \\
ALT D5 & 58.00 & 230.00 & 133.97 & 57.24 \\
ALT D to normal (days) & 5.00 & 9.00 & 6.97 & 1.47 \\
AST D1 & 96.00 & 477.00 & 267.80 & 101.19 \\
AST D3 & 51.00 & 325.00 & 152.07 & 66.17 \\
AST D5 & 39.00 & 117.00 & 66.37 & 22.39 \\
AST D to normal (days) & 3.00 & 7.00 & 5.27 & .98 \\
\hline
\end{tabular}

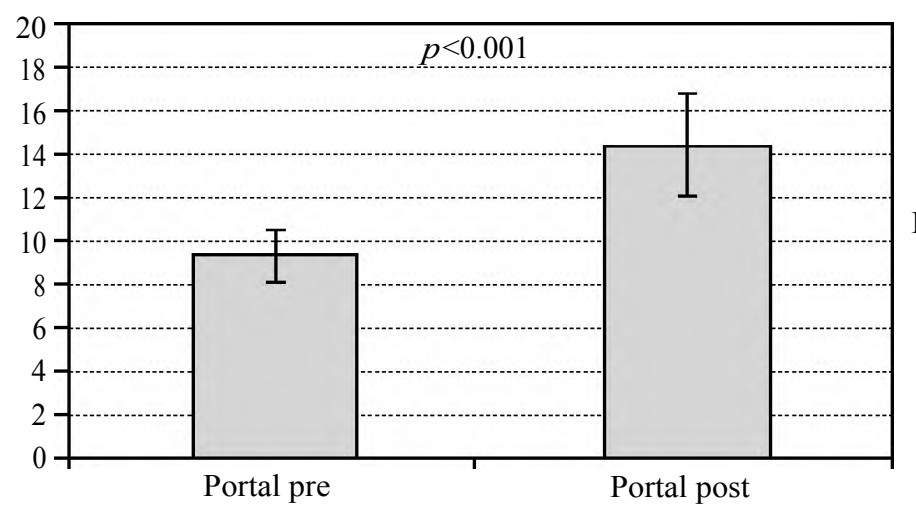

Fig. (3): The mean difference in PVP pre \& post clamping of portal vein 
Table (4): Significance of correlations between portal pressure changes and level of ALT, AST, bilirubin, INR, Albumin in day 1, 3 and 5 post-operative and their duration to normalize.

\begin{tabular}{ll}
\hline Liver functions & $p$-value \\
\hline ALT D1 & .022 \\
ALT D3 & $<0.001$ \\
ALT D5 & $<0.001$ \\
ALT to normal (days) & $<0.001$ \\
AST D1 & .064 \\
AST D3 & .002 \\
AST D5 & .004 \\
AST to normal (days) & .020 \\
BIL T D1 & .140 \\
BIL T D3 & .129 \\
BIL T D5 & .009 \\
BIL T to normal (days) & .001 \\
BIL D D1 & .085 \\
BIL D D3 & .468 \\
BIL D D5 & .169 \\
BIL D to normal (days) & $<0.001$ \\
INR D1 & .068 \\
INR D3 & .230 \\
INR D5 & .657 \\
INR to normal (days) & .171 \\
Albumin D1 & .413 \\
Albumin D3 & .835 \\
Albumin D5 & .005 \\
Albumin to normal (days) & .023 \\
\hline
\end{tabular}

\section{Discussion}

It has been hypothesized that an increase in PVP is necessary for liver regeneration to occur after hepatectomy. On the other hand, several reports have hypothesized that excessive portal hypertension and over perfusion can injure the remnant liver and lead to dysfunction [8].

The changes in portal hemodynamics occurring during donor hepatectomy and their effect on liver function have not been studied frequently, this represented the main motive for this study.

Mohammed G et al., in 2015 conducted a study in dogs, they observed a rise in portal pressure after $60 \%$ hepatectomy up to $16.5 \mathrm{mmHg}$ which is a $33 \%$ rise in comparison to base line value with mean rise $6.5 \mathrm{mmHg}$ [3].

A study conducted by Marc-Antoine Allard et al., in 2013 a prospective on 81 living donors who donated their right lobe, from which they concluded that the post hepatectomy PVP significantly increased with a mean of $15.4 \mathrm{mmHg}$ [9].

A study conducted by D. Takashi T et al., in 1985 on 22 non-cirrhotic patients underwent hepatic resection (13 HCC, 5 hemangioma, 1 benign cyst, 2 metastasis and 1 gall bladder carcinoma). From which 14 undergoing major resection (more tham
3 segments), changes in portal pressure before and after hepatic resection were monitored in patients. The mean rise in portal pressure post hepatectomy was $4 \mathrm{mmHg}(p 0.05)[10]$

In 1991 a prospective study was done by Shoichiro et al., in 1991 to study the hemodynamic changes on dogs, the mean rise of portal pressure $5.5 \mathrm{mmHg}(p<0.001)[11]$

In the present study, a significant rise in portal pressure after clamping of the right portal vein was observed (mean rise $5.33 \mathrm{mmHg}, p<0.001$ ).

Although different hypotheses have been proposed to explain this result, many questions remain not answered, external hepatectomy results in parenchymal loss, a reduced intra-hepatic vascular bed and increased hepatic portal resistance due to transient sinusoidal narrowing with higher portal flow per gram of remnant liver [3].

In 2012, a study conducted by Gupta et al., on 50 living donor donating their right lobe with residual volume at least $30 \%$ and correlating the changes in portal pressure with liver functions, he found that the rise in portal pressure was significantly associated with serum level of bilirubin on the $3 \mathrm{rd}$, 5 th post-operative day, serum level of ALT on the 3 rd post-operative day $(p<0.05)$ and duration of normalization of serum bilirubin $(p<0.05)$ [1]

In 2003 study conducted by Ki Hwan Kwon on 50 living donors assessed post-operative liver functions following living donor right hepatectomies. His results showed that there was no significant correlation between the rise in AST, ALT, total bilirubin and both the residual volume and the steatosis. The study concluded that because the portal venous flow velocity had a triggering effect on liver regeneration, the increased portal blood flow in the donors who got a less amount of remnant liver might influence more rapid regeneration, but was not convincing this hypothesis because the portal pressure was not measured in the donors before and after harvesting [12].

In the present study, analysis of the data indicated that the rise in portal pressure was significantly associated with duration till normalization of ALT, AST, bilirubin and albumin with $p$-value $(<0.001),(0.020),(<0.001)$, and value $(0.023)$, but not associated with INR level and time of normalization.

It should be noted that we excluded patients with residual volume of less than $35 \%$, however, these results are a motive to expand our patient's 
selection to a volume of $30 \%$ without compromising the donor safety.

\section{References}

1- GUPTA S., YADAV A., GOYAL N., WADHAWAN M. and VASUDEVAN K.: Changes in Portal Hemodynamics Predict the Pattern of Functional Remnant. Regeneration Post Donor Hepatectomy Supplement toTransplantation November, 27, Volume 94 Number 10S, 2012.

2- HAMADA T., KAMADA H., HAYASHI T., NISHIOKA J., GABAZZA E.C., ISAJI S., UEMOTO S. and SUZUKI K.: "Protein C Inhibitor Regulates Hepatocyte Growth Factor Activator-Mediated Liver Regeneration in Mice," Gut., 57, pp., 365-73, 2008.

3- MOHAMMAD GOLRIZ, ALI MAJLESARA, SAROA EL-SAKKA, MARYAM ASHRAFI, JALAL ARWIN, NASSIM FARD, HANNA RAISI, ARMAN EDALATPOUR and ARIANEB MEHRABI: Small for Size and Flow (SFSF) syndrome: An alternative description for posthepatectomy liver failure. Clinics and Research in Hepatology and Gastroenterology, 40: 267-75, 2016.

4- FU Y., ZHANG H.B., YANG N., ZHU N., SI-MA H., CHEN W., et al.: Porcinepartial liver transplantation without veno-venous bypass: Aneffective model for smallfor-size liver graft injury. Transplant Proc., 43: 1953-61, 2011.

5- AKIMARU K., ONDA M., TAJIRI T., YOSHIDA H., YOKOMURO S., MAMADA Y., et al.: Hypersplenism induced by hepatectomy. Hepatogastroenterology, 48: 1170-5, 2001.

6- SAKAMOTO S., UEMOTO S., URYUHARA K., et al.:
Graft size assessment and analysis of donors for living donor liver transplantation using right lobe. Transplantation, 71: 1407, 2001.

7- KELLY D.M., DEMETRIS A.J., FUNG J.J., MARCOS A., ZHU Y., SUB-BOTIN V., et al.: Porcine partial liver transplantation: A novelmodel of the "small-for-size" liver graft. Liver Transpl., 10: 253-63, 2004.

8- YAGI S., IIDA T., TANIGUCHI K., HORI T., HAMADA T., FUJII K., et al.: Impact of portal venous pressure on regeneration and graft damage after living-donor liver transplantation. Liver Transpl., 11: 68-75, 2005.

9- MARC-ANTOINE ALLARD, RENÉADAM, PÉTRUOCTAV BUCUR, et al.: Post hepatectomy Portal Vein Pressure Predicts Liver Failure and Mortality after Major Liver Resection on Noncirrhotic Liver Ann. Surg., 258: 822-30, 2013

10- TAKASHI KANEMATSU, KENJI TAKENAKA, TOSHIYA FURUTA, et al.: Acute Portal Hypertension Associated With Liver Resection. Arch. Surg., 120: 1303-130, 1985.

11-SHOICHIRO SUMI, KAZUTOMO INOVE, RYUICHIRO DOI, MITSUTOSHI YUN, MASAFUMI KOGIRE and TAKAYOSHI TOBE.: Hemodynamic changes in progressively Lobectomized liver of the dog, correlation with remnant percentage og the liver Dig. Surg., 8: 28-33, 1991.

12- KI HWAN KWON, YANG WAN KIM, SOON LEE KIM, KYUNG SIK KIM, WOO JUNG LEE and JIN SUB CHOI: Post-operative liver regeneration and complication in live liver donor after partial hepatectomy for living donor liver transplantation. Yoseni Medical Journal Vol., 44, No.6, P. 1069-77, 2003.

\title{
هل تؤثر التغيرات التى تحلدث فى ضغد الوريد البابى الكبلى فى في المتبرع الحى على وظائف الكبل
}

\author{
زداعة الكبد من المتبرع الحى أصبحث بديلا المتبرع المتوفى. \\ وقد قمنا في الدراسة الحالية بدراسة المتفيرات التى قد تحدث فى الوريد البابى الكبدى ومدى تأثيرها على وظائف الكبد. \\ وتم إجراء عملية إستئصال للفص الأيمن من • ب متبرع حى للقلهم للمستقبل وتم قياس ضغط الويد البابي الكبدى أثثاء العملية قبل وبعد \\ غلق الوريد البابى الكبدى الآيمن.
}

وقد تبين أنه هناك زيادة ملحوظة في ضغط الويد البابى الكبدى وأنه كلما زاد ضغط الوريد البابى الكبدى كلما حدث إختلال مؤقت فى إنى

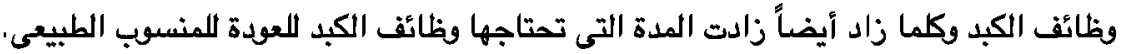

